Counsellia: Jurnal Bimbingan dan Konseling

Volume 11 (1) 43 - 55 Mei 2021

ISSN: 2088-3072 (Print) / 2477-5886 (Online)

DOI: $10.25273 /$ counsellia.v11i18670

Available online at: http://e-journal.unipma.ac.id/index.php/JBK

\title{
POTRET EVALUASI PROGRAM BIMBINGAN DAN KONSELING DI SEKOLAH MENENGAH ATAS
}

\author{
Evi Winingsih ${ }^{\mathbf{1}}$, \\ Fakultas Ilmu Pendidikan, Universitas Negeri Surabaya, Surabaya \\ email: eviningsih@unesa.ac.id
}

\begin{abstract}
Abstrak: Evaluasi dalam pelayanan bimbingan dan konseling merupakan hal yang idealnya dilakukan oleh guru Bimbingan dan Konseling. Prosedur evaluasi yang tepat akan memberikan banyak keuntungan bagi guru Bimbingan dan konseling. Evaluasi memberikan umpan balik kepada guru bimbingan dan konseling untuk mengembangkan dan memperbaiki program. Evaluasi juga memberikan informasi kepada pimpinan tentang perkembangan peserta didik dan upaya perbaikannya. Penelitian ini bertujuan untuk mengetahui bagaiamana proses evaluasi yang ada di SMA. Metode Penelitian menggunakan pendekatan kualitatif deskriptif. Teknik pengumpulan data adalah wawancara, observasi dan dokumentasi. Teknik pengambilan sampel dilakukan melalui prosedur nonprobability sampling. Hasil dari penelitian ini menunjukkan keberagaman dalam proses evaluasi yang dilakukan sekolah menengah atas dibeberapa daerah. Terdapat 6 (enam) tipe evaluasi yang dilakukan oleh guru bimbingan dan konseling di sekolah menengah atas. Hasil penelitian juga menggambarkan teknik evaluasi dan tujuan sekolah melakukan evaluasi. Harapan kami hasil penelitian ini dapat memberikan informasi untuk meningkatakan kualitas evaluasi pada pelayanan Bimbingan dan Konseling di Indonesia.
\end{abstract}

Kata Kunci: Evaluasi, Bimbingan dan Konseling.

\begin{abstract}
Evaluation of guidance and counseling services should ideally be conducted periodically and continuously. Appropriate evaluation procedures will provide many benefits for teachers Guidance and counseling. Evaluation gives teacher guidance and counseling feedback to develop and improve programs. Evaluations also provide information to leaders about student development and improvement efforts. Proper evaluation results will help the counselor in achieving the goals of guidance and counseling services. This study aims to determine how the evaluation process is in high school. The research method uses a descriptive qualitative approach. Data collection techniques are interviews and observation. The sampling technique was carried out through a nonprobability sampling procedure. The results of this study indicate diversity in the evaluation process carried out by high schools. There are 6 (six) types of evaluations conducted by guidance and counseling teachers in high schools. The results of the study also illustrate the evaluation techniques and the purpose of schools conducting evaluations. We hope that the results of this study can provide information to improve the quality of evaluation in the Guidance and Counseling services in Indonesia.
\end{abstract}

Keywords : Evaluation, Guidance and Counseling. 
Citation: Winigsih. (2021). Potret Evaluasi Program Bimbingan Dan Konseling di Sekolah Menengah Atas . Counsellia: Jurnal Bimbingan dan Konseling, 11(1), 43 - 55. Doi.org/10.25273/counsellia.v11i18670

\section{(cc) $\mathrm{EY}-\mathrm{NC}-\mathrm{SA}$}

Copyright @2021 Counsellia: Bimbingan dan Konseling

Published by Universitas PGRI Madiun. This work is licensed under the Creative Commons Attribution-NonCommercialShareAlike 4.0 International License

\section{PENDAHULUAN}

Bimbingan dan konseling (BK) merupakan komponen integral dalam sistem pendidikan di sekolah. Konselor sekolah perlu menyadari dampak dari faktor kontekstual dan lingkungan, mereka juga perlu mempromosikannya secara aktif melalui kolaborasi, advokasi, dan intervensi tingkat sistem lainnya (Galassi, 2017). Keberadaan program BK di sekolah sebagai fasilitas penyelenggara pemberian program dalam rangka mewujudkan perkembangan optimal peserta didik. Program BK menjadi salah satu hal utama dalam mewujudkan perkembangan optimal perserta didik. Pelaksanaan program yang telah disuun perlu dilakukan evaluasi yang mendalam agar diketahui keefektifan program terebut.

Program BK dikembangkan sesuai dengan kebutuhan siswa. Program yang telah dibuat kemudian diimplementasikan dan dijalankan agar hasil dan tindak lanjutnya dapat dilakukan. "Evaluation consist of making systematic judgements of the relative effectiveness with which goals are attained in relation to special standards" (Gysbers \& Henderson, 2014; Shertzer \& Stone, 1966; Sink \& Spencer, 2005). Pendapat tersebut menjelaskan bahwa evaluasi terdiri dari proses penilaian yang sistematis terhadap keefektifan dari tujuan yang akan dicapai dengan membandingnya pada standar tertentu. Guru BK perlu menetapkan sebuah tujuan dalam pengembangan dan pelaksanaan program. Hal ini akan menjadi arah dalam pelaksanaan BK di sekolah. Tujuan yang telah ditetapkan ini yang kemudian di korelasikan dengan standar ideal pelaksanaan BK berdasarkan Standar Kemampuan dan Keterampilan Peserta Didik (SKKPD). Pendampingan dan supervisi BK diperlukan untuk menjamin terselenggaranya layanan BK yang optimal di sekolah. Sayangnya, sebagian besar praktik pelayanan BK, evaluasi dan pertanggungjawaban BK di sekolah tidak dilaksanakan secara tepat (Sugiyo \& Muslikah, 2018).

Hasil evaluasi akan lebih efektif jika disosialisasikan dalam rangka mendapatkan umpan balik dari pengguna atau pihak terkait. Memberikan hasil evaluasi kepada pengguna utama dengan cara yang dipahami oleh mereka akan membantu pemanfaatan evaluasi (Sink, Cooney, \& Adkins, 2017). Evaluasi ini dapat pula diartikan sebagai proses pengumpulan informasi (data) untuk mengetahui efektivitas (keterlaksanaan dan ketercapaian) kegiatan-kegiatan yang telah dilaksanakan dalam upaya mengambil keputusan. Menurut Moh.Surya dan Rochman Natawidjaja (Tohirin \& Pd, 2007) menyatakan: "Evaluasi juga bisa bermakna upaya menelaah atau menganalisis program layanan bimbingan dan konseling yang telah dan sedang dilaksanakan untuk mengembangkan dan memperbaiki program secara khusus dan program pendidikan di sekolah secara umum". Menurut W.S Winkel (Sukardi \& Kusmawati, 2008) Evaluasi program bimbingan adalah usaha menilai efisiensi dan efektivitas pelayanan bimbingan itu sendiri demi peningkatan mutu program bimbingan.

Proses evaluasi program merupakan salah satu faktor pendukung dalam pelaksanaan layanan Bimbingan dan Konseling. Bukan hanya sekedar melaksanakan tangungjawab profesional, namun Konselor kemungkinan mampu melakukan perbaikan 
secara tepat dengan melakukan evaluasi. Selain itu melalui evaluasi guru BK juga akan mampu melihat tingkat keberhasilan dari sebuah program. Pentingnya proses evaluasi tidak diimbangi dengan proses evaluasi yang di lakukan secara berkelanjutan dan tepat. Hasil penelitian menunjukkan pengaruh sikap guru BK terhadap proses evaluasi yang dijalankan di sekolahnya (Hapsyah et al., 2019).

Penelitian yang dilakukan oleh (Sukardi \& Kusmawati, 2008), memaparkan bahwa fakta di lapangan terkait pelaksanaan evaluasi menunjukkan bahwa tidak semua konselor melaksanakan evaluasi, sehingga tidak ada perbaikan program layanan Bimbingan dan Konseling dari tahun ke tahun. Banyak alasan konselor tersebut tidak melakukan evaluasi program layanan, antara lain: ketidakmampuan konselor melakukan evaluasi, kurangnya minat konselor untuk belajar melakukan evaluasi program layanan bimbingan dan konseling, dan minimnya pelatihan yang diberikan untuk mengevaluasi program.

Program evaluasi merupakan rangkaian kegiatan yang dilakukan dengan sengaja untuk melihat tingkat keberhasilan program (Arikunto, 2019). Program evaluasi adalah kegiatan yang disepakati untuk dipelajari dan disetujui. Evaluasi program biasanya dilakukan untuk menentukan kebijakan selanjutnya. melalui evaluasi program. Tahap evaluasi tidak hanya dilakukan dengan menggunakan prosedur yang sistematis, terperinci, dan telah disetujui secara cermat.

Evaluasi program bimbingan dan konseling di sekolah ini merupakan bantuan proses atau penilaian untuk program evaluasi tingkat atas yang berkaitan dengan pelaksanaan program bimbingan dan konseling di sekolah dengan persetujuan persetujuan atau tolok ukur sesuai dengan program pembinaan dilaksanakan (Sukardi \& Kusmawati, 2008). Tujuan evaluasi adalah untuk menentukan nilai suatu program, berbagai kegiatan dalam program tersebut, dan staf yang terlibat dalam program tersebut, untuk kemudian mengambil keputusan atau tindakan di masa depan. Evaluasi terdiri dari membuat penilaian sistematis tentang keefektifan relatif dengan tujuan yang dicapai dalam kaitannya dengan standar khusus (Shertzer \& Stone, 1966).

Jenis evaluasi program bimbingan dan konseling menurut Panduan Operasional pelayanan BK ada 2 (dua) jenis evaluasi, yaitu evaluasi proses dan evaluasi hasil.

1. Evaluasi proses adalah kegiatan evaluasi yang dilakukan melalui analisis hasil penilaian proses selama kegiatan pelayanan bimbingan dan konseling berlangsung. Fokus penilaian adalah keterlibatan unsur-unsur dalam pelaksanaan kegiatan bimbingan dan konseling. Dalam evaluasi ini, guru bimbingan dan konseling atau konselor juga membandingkan keberhasilan pelaksanaan program dengan standarstandar program yang telah ditetapkan sebelumnya.

2. Evaluasi hasil adalah kegiatan evaluasi yang dilakukan untuk memperoleh informasi tentang keefektifan layanan bimbingan dan konseling dilihat dari hasilnya. Evaluasi hasil pelayanan bimbingan dan konseling ditujukan pada hasil yang dicapai oleh peserta didik yang menjalani pelayanan bimbingan dan konseling. Pencapaian ini diorientasikan pada tingkat pengentasan masalah dan tugas perkembangan peserta didik/konseli, oleh karena itu fokus penilaian dapat diarahkan pada berkembangnya :

a. Pemahaman diri, sikap, dan perilaku yang diperoleh berkaitan dengan materi/topik/masalah yang dibahas.

b. Perasaan positif sebagai dampak dari proses atau materi/topic/masalahi yang dibahas.

c. Rencana kegiatan yang akan dilaksanakan pasca layanan dalam rangka mewujudkan upaya pengembangan potensi dan pengentasan masalah. 
Evaluasi program bimbingan dan konseling di sekolah adalah segala upaya tindakan atau proses untuk menentukan derajat kualitas kemajuan kegiatan yang berkaitan dengan pelaksanaan program bimbingan dan konseling di sekolah dengan mengacu pada kriteria atau patokan-patokan tertentu sesuai dengan program bimbingan yang dilaksanakan (Sukardi, n.d.). Tujuan evaluasi adalah untuk menentukan nilai suatu program, berbagai kegiatan di dalam program, dan para staff yang terlibat dalam program tersebut, untuk kemudian mengambil keputusan atau tindakan-tindakan di masa mendatang.

Penetapan kebijakan akan menentukan data yang digunakan sebagai dasar penilaian yang tepat, akurat, dan lengkap. Ada empat jenis kebijakan tindak lanjut yang perlu diambil setelah evaluasi program dilakukan, sebagai berikut:

1) Kegiatan tindak lanjut. Berdasarkan hasil evaluasi program ini sangat bermanfaat dan dapat terlaksana dengan baik tanpa kesulitan, serta kesepakatan yang berkualitas.

2) Kegiatan diselesaikan dengan perbaikan. Hal ini dikarenakan data yang terkumpul merupakan hasil dari program yang sangat bermanfaat namun implementasinya kurang baik atau kualitas pencapaiannya kurang tinggi.

3) Aktivitas. Hal ini karena data yang terkumpul menunjukkan bahwa manfaat dari hasil program yang tinggi perlu dipersiapkan dengan lebih baik. Dalam hal ini mungkin perlu diubah.

4) Kegiatan tidak dapat dilanjutkan. Hal ini karena dari data yang terkumpul diketahui bahwa hasil program yang terkumpul masih kurang bermanfaat, ditambah lagi dalam pelaksanaannya banyak kendala.

Pelaksanaan proses evaluasi dilakukan melalui pengelolaan layanan bimbingan dan konseling yang harus dinilai. Menurut Panduan Operasional Penyelenggaraan Bimbingan dan Konseling disebutkan bahwa mekanisme pengelolaan bimbingan dan konseling mencakup tahapan analisis kebutuhan, perencanaan, pelaksanaan, evaluasi, pelaporan, dan tindak lanjut pengembangan program. Kegiatan dalam evaluasi bimbingan dan konseling, yaitu mencakup proses mengumpulkan dan menganalisis informasi tentang efisiensi, efektifvitas, dan dampak dari program maupun kegiatan layanan bimbingan dan konseling terhadap perkembangan peserta didik baik pada bidang pribadi, sosial, belajar, maupun karir. Evaluasi juga perlu direncanakan dan dilaksanakan dengan cara yang memungkinkan untuk melacak kemajuan pemerataan (Whiston, Mitts, \& Li, 2019). Adanya prosedur yang ketat membuat proses evaluasi menjadi penting untuk dilihat oleh guru bimbingan dan konseling yang melakukan evaluasi di sekolah. Penelitian ini akan menggambarkan evaluasi sekolah di sekolah.

Pada artikel ini peneliti bertujuan untuk melakukan: 1) identifikasi pelaksanaan evaluasi pada jenjang SMA terpilih; 2) melakukan telaah data pelaksanaan evaluasi pelayanan BK di SMA terpilih. Berdasarkan tujuan tersebut maka akan diperoleh data tentang 1) keterlaksanaan evaluasi dan 2) jenis penerapan evaluasi di SMA. Penulis berharap artikel ini mampu memberikan informasi tentang pelaksanaan evaluasi dan prosedurnya sehingga dapat dijadikan sebagai tindakan pengembangan maupun kuratif dalam pelaksanaan evaluasi di SMA.

\section{METODE PENELITIAN Rancangan Penelitian}

Penelitian ini menggunakan penelitian kualitatif dengan ancangan deskriptif/interpretative. Tujuan penelitian ini adalah untuk mendapatkan informasi secara mendalam tentang proes evaluasi program dari para narasumber dalam hal ini adalah guru 
BK. Ancangan deskritif/interpretative dalam riset kualtatif deskriptif 'mensyahadati', mengikat-diri, atau berikrar pada tujuan mengurai atau memeriksa fenomena dan data menurut konteks, inteni, dan prosesnya secara mendalam, sampai pada makna terdalamnya (Mappiare, 2013).

\section{Sumber Data}

Populasi dari penelitian ini adalah sebagian kota di Jawatimur. Teknik pengambilan sampel yang digunakan dalam penelitian ini adalah teknik nonprobability sampling dengan teknik kuota sampling. Sampel yang diambil ditentukan berdasarkan kuota dan sampai data yang didapatkan mengalami kejenuhan tidak ada informasi yang lain dari sampel. Seperti yang dijelaskan oleh Lincolh dan Guba bahwa "if the purpose is to maximize information, then sampling is terminated when no new informaion is forthcoming from newly sampled units; this redundancy is the primary criterion" (Lincoln, n.d.). Jumlah narasumber dalam penelitian ini adalah 20 SMA di Jawa Timur dari 8 (delapan kabupaten) yakni: Surabaya, Gresik, Sidoarjo, Mojokerto, Jombang, Kediri, Ketapang, dan Madiun.

\section{Teknik Pengumpulan Data}

Pengumpulan data dilakukan dengan wawancara, dan studi pustaka. "In-depth interviews may be described as a conversation with a purpose. The researcher's purpose is to gain insight into certain issues using a semi-structured interview guide. If conducted well, this can feel like a conversation for the interviewee" (Hennink, Hutter, \& Bailey, 2020) Hennink menyatakan bahwa: "Wawancara mendalam dapat digambarkan sebagai percakapan dengan suatu tujuan. Tujuan peneliti adalah untuk mendapatkan wawasan tentang masalah tertentu menggunakan panduan wawancara semi-terstruktur. Jika dilakukan dengan baik, ini akan terasa seperti percakapan bagi orang yang diwawancarai.

Telaah pustaka dilakukan dengan melihat dokumen seperti bimbingan dan konseling; Program konselor, laporan pelaksanaan program, laporan evaluasi program, dll. Review pustaka merupakan sarana penunjang peneliti dalam mengumpulkan data atau informasi dengan membaca surat, pengumuman, ringkasan rapat, pernyataan tertulis mengenai kebijakan tertentu dan bahan tertulis lainnya (Lichtman, 2012).

\section{Teknik Analisis Data}

Analisis data dalam penelitian kualitatif dilakukan pada saat pengumpulan data berlangsung, dan setelah selesai pengumpulan data setelah selesai pengumpulan data dalam jangka waktu tertentu. Miles and Hubeman mengemukakan bahawa aktivita datam penelitian kualitatif dilakukan secara interaktif dan berlangsung secara terus menerus sampai tuntas, sampai datanya jenuh (Huberman \& Miles, 2002). Teknik analisis data dilakukan melalui teknik triangulasi data dari berbagai sumber data wawancara, obervasi, maupun dokumentasi.

\section{HASIL DAN PEMBAHASAN}

\section{Hasil}

Data yang diperoleh berdasarkan hasil penelitian yang dilakukan oleh peneliti dengan menggunakan teknik pengumpulan data wawancara, obervasi dan dokumentasi didapatkan data sebagai berikut: 
Table 1. gambaran evaluasi di sekolah

\begin{tabular}{|c|c|c|c|}
\hline \multirow[t]{2}{*}{ No } & \multirow[t]{2}{*}{ Nama sekolah } & Pelaksanaan evaluasi & \multirow[t]{2}{*}{ Keterangan } \\
\hline & & Ya $\quad$ Tidak & \\
\hline 1 & $\begin{array}{l}\text { SMK N } 1 \\
\text { KEDIRI }\end{array}$ & $\sqrt{ }$ & $\begin{array}{l}\text { Evaluasi yang dilakukan adalah } \\
\text { evaluasi proses dan evaluasi } \\
\text { hasil. Evaluasi proses } \\
\text { dilaksanakan setiap kali } \\
\text { program dijalankan. Sedangkan } \\
\text { evaluasi hasil dilakukan setiap } \\
\text { akhir semester dengan } \\
\text { menyebarkan instrument } \\
\text { kepuasan pelanggan }\end{array}$ \\
\hline 2 & $\begin{array}{l}\text { SMA Wijaya } \\
\text { Putra }\end{array}$ & $\sqrt{ }$ & $\begin{array}{l}\text { Evaluasi dilakukan } 3 \text { kali dalam } \\
1 \text { tahun yakni: evaluasi internal } \\
1 \text { bulan sekali, evaluasi dengan } \\
\text { walikelas setiap } 1 \text { minggu } \\
\text { sekali, evaluasi dengan seluruh } \\
\text { pihak sekolah dilaksanakan satu } \\
\text { kali dalam } 1 \text { semester }\end{array}$ \\
\hline 3 & $\begin{array}{l}\text { SMA N } 2 \\
\text { Mojokerto }\end{array}$ & $\sqrt{ }$ & $\begin{array}{l}\text { Pelaksanaan evaluasi dilakukan } \\
\text { namun masih belum optimal, } \\
\text { hal ini terlihat dari belum } \\
\text { adanya (1) pengadministrasian } \\
\text { yang baik dari hasil evaluasi } \\
\text { proses yang dilakukan. (2) } \\
\text { program yang dikembangkan } \\
\text { masih belum diselesaikan } \\
\text { hingga tahun ajaran berjalan }\end{array}$ \\
\hline 4 & $\begin{array}{l}\text { SMAN } 13 \\
\text { Surabaya }\end{array}$ & $\sqrt{ }$ & $\begin{array}{l}\text { Evaluasi dilakukan sekali dalam } \\
\text { satu semester. Pelaksanaan } \\
\text { evaluasi seperti ini disebut } \\
\text { evaluasi sumatif (harusnya ada } \\
\text { evaluasi formatifnya juga). } \\
\text { Hasil evaluasi akan } \\
\text { dideseminasiakn dengan pihak } \\
\text { sekolah untuk ditidak lanjuti }\end{array}$ \\
\hline 5 & SMAN 1 CERME & $\sqrt{ }$ & $\begin{array}{l}\text { Evaluasi dilakukan sekali di } \\
\text { akhir semester atau kenaikan } \\
\text { kelas. Item yang di evaluasi } \\
\text { adalah kinerja guru BK, } \\
\text { perangkat pembelajaran, media }\end{array}$ \\
\hline
\end{tabular}




\begin{tabular}{|c|c|c|c|c|}
\hline \multirow[t]{2}{*}{ No } & \multirow[t]{2}{*}{ Nama sekolah } & \multicolumn{2}{|c|}{ Pelaksanaan evaluasi } & \multirow[t]{2}{*}{ Keterangan } \\
\hline & & $\mathbf{Y a}$ & Tidak & \\
\hline & & & & BK. \\
\hline 6 & $\begin{array}{l}\text { SMAN } 22 \\
\text { Surabaya }\end{array}$ & $\sqrt{ }$ & & $\begin{array}{l}\text { Evaluasi dilakukan seminggu } \\
\text { sekali untuk melihat } \\
\text { keterlaksanaan program BK. }\end{array}$ \\
\hline 7 & $\begin{array}{l}\text { SMAN } 3 \\
\text { TARUNA } \\
\text { ANGKASA } \\
\text { MADIUN }\end{array}$ & $\sqrt{ }$ & & $\begin{array}{l}\text { Evaluasi dilaksanakan program } \\
\text { bimbingan dan konseling } \\
\text { dilaksanakan tiap tahun untuk } \\
\text { kemudian di laporkan kepada } \\
\text { pihak sekolah }\end{array}$ \\
\hline 8 & $\begin{array}{l}\text { SMKN } 10 \\
\text { Surabaya }\end{array}$ & $\sqrt{ }$ & & $\begin{array}{l}\text { Evaluasi dilakukan sekali dalam } \\
1 \text { tahun }\end{array}$ \\
\hline 9 & $\begin{array}{l}\text { SMAN } 1 \\
\text { Driyorejo }\end{array}$ & $\sqrt{ }$ & & $\begin{array}{l}\text { Evaluasi dilakukan tiap kali } \\
\text { pelayanan BK diberikan, } \\
\text { bulanan dan tahunan data } \\
\text { pengadministrasian juga } \\
\text { terarsip dengan baik. }\end{array}$ \\
\hline 10 & $\begin{array}{l}\text { SMA } \\
\text { Muhammadiya } 4 \\
\text { Surabaya }\end{array}$ & & $\sqrt{ }$ & $\begin{array}{l}\text { Belum melakukan evaluasi } \\
\text { untuk mengukur ketercapaian } \\
\text { program BK. Evaluasi } \\
\text { dilakuakan } 2 \text { tahun yang lalu. } \\
\text { Hal ini karena guru BK di sana } \\
\text { bukan berasal dari S1 BK }\end{array}$ \\
\hline 11 & $\begin{array}{l}\text { SMAN Jatirogo } \\
\text { Jombang }\end{array}$ & $\sqrt{ }$ & & $\begin{array}{l}\text { Evaluasi dilakukan tiap } \\
\text { semester. Hal ini terbukti } \\
\text { dengan adanya buku laporan } \\
\text { dan catatan program layanan } \\
\text { yang sudah berjalan dan } \\
\text { dilaporkan kepada kepala } \\
\text { sekolah. }\end{array}$ \\
\hline 12 & SMAN 1 Krian & $\sqrt{ }$ & & $\begin{array}{l}\text { Evaluasi dilakukan setiap } 1 \\
\text { semester sekali. Pelaksanaan } \\
\text { evaluasi tidak diberlakukan } \\
\text { untuk semua layanan hanya } \\
\text { layanan tertentu yang dianggap } \\
\text { sangat membutuhkan proses } \\
\text { evaluasi }\end{array}$ \\
\hline
\end{tabular}




\begin{tabular}{|c|c|c|c|}
\hline \multirow[t]{2}{*}{ No } & \multirow[t]{2}{*}{ Nama sekolah } & Pelaksanaan evaluasi & \multirow[t]{2}{*}{ Keterangan } \\
\hline & & $\begin{array}{ll}\text { Ya } & \text { Tidak } \\
\end{array}$ & \\
\hline 13 & $\begin{array}{l}\text { SMAN } 1 \\
\text { KETAPANG }\end{array}$ & $\sqrt{ }$ & $\begin{array}{l}\text { Evaluasi dilakukan tiap } \\
\text { semester }\end{array}$ \\
\hline 14 & $\begin{array}{l}\text { SMA NU } 1 \\
\text { GRESIK }\end{array}$ & $\sqrt{ }$ & $\begin{array}{l}\text { Evaluasi dilaksanakan minimal } \\
1 \text { tahun sekali. Namun ketika } \\
\text { ada layanan yang tidak berjalan } \\
\text { dengan baik akan dilakukan } \\
\text { tindak lanjut berupa evaluasi }\end{array}$ \\
\hline 15 & $\begin{array}{l}\text { SMAN } 1 \\
\text { Kebomas }\end{array}$ & $\sqrt{ }$ & $\begin{array}{l}\text { Evaluai dilaksanakan meliputi } 4 \\
\text { bidang BK. Evaluasi program } \\
\text { dilakukan dengan melibatkan } \\
\text { stakeholder seprti; kepala } \\
\text { sekolah, wakil kepala sekolah }\end{array}$ \\
\hline 16 & SMAN 3 Sidoarjo & $\sqrt{ }$ & $\begin{array}{l}\text { Evaluasi laseg, laijapan, dan } \\
\text { lapjapang tidak dilakukan } \\
\text { dalam kegiatan pelayanan. } \\
\text { Evaluasi terhadap program } \\
\text { layanan dilakukan setiap akhir } \\
\text { semester }\end{array}$ \\
\hline 17 & SMAN 2 Sidoarjo & $\sqrt{ }$ & $\begin{array}{l}\text { Evaluasi dilakukan, namun } \\
\text { tidak menyeluruh dan belum } \\
\text { terarsipkan dengan baik }\end{array}$ \\
\hline 18 & $\begin{array}{l}\text { SMK Kemala } \\
\text { Bhayangkari } \\
\text { Waru }\end{array}$ & $\sqrt{ }$ & $\begin{array}{l}\text { Evaluasi jangka pendek } \\
\text { dilakukan jika dibutuhkan dan } \\
\text { segera ditindak lanjuti. Evaluasi } \\
\text { jangka Panjang dilakukan tiap } \\
\text { tahun untuk memperbaiki } \\
\text { kinerja guru BK }\end{array}$ \\
\hline 19 & $\begin{array}{l}\text { SMKN } 12 \\
\text { Surabaya }\end{array}$ & $\sqrt{ }$ & $\begin{array}{l}\text { Evaluasi dilakukan setiap akhir } \\
\text { semester yang kemudian } \\
\text { dilaporkan kepada pimpinan } \\
\text { untuk ditindak lanjuti. Proses } \\
\text { evaluasi dilakukan dengan } \\
\text { melibatkan guru maple, kepala } \\
\text { sekolah, TU, dan wakil kepala } \\
\text { sekola }\end{array}$ \\
\hline 20 & SMAN 1 & $\sqrt{ }$ & Evaluasi tidak dilaksanakan \\
\hline
\end{tabular}




\begin{tabular}{llll}
\hline No & Nama sekolah & \multicolumn{1}{c}{ Pelaksanaan evaluasi } & \multicolumn{1}{c}{ Keterangan } \\
\cline { 2 - 3 } & Ya ${ }^{\text {Tidak }}$ & \\
\hline Menganti & & secara terstruktur, hal ini \\
& & terlihat tidak adanya analisis \\
& & dan tindka lanjut dari \\
& & pelaksanaan program. Namun \\
& & kegiatan evaluasi di lakukan \\
& & setahun sekali \\
\hline
\end{tabular}

Hasil penelitian di atas diambil dari 20 (dua puluh) Sekolah Menengah Atas di sebagian kota di jawa timur. Sekolah yang dimabil sebagai sampel tersebar di delapan kota yakni: Gresik, Surabaya, Sidoarjo, Mojokerto, Madiun, Ketapang, Kediri, dan Jombang. Dari dua puluh sekolah 19 sekolah telah melakukan evaluasi program, sedang satu sekolah tidak melakukan evaluasi program BK selama dua tahun terakhir. Data di atas telah melalui proses analisis data dengan mengkorelasi dan mereduksi data dari wawancara, obervasi dan dokumentasi

\section{Pembahasan}

Manajemen masing-masing sekolah menggunakan teori yang berbeda tetapi pada dasarnya sama yaitu menganalisis kebutuhan sekolah, perencanaan, pengorganisasian, pengaktualisasian, dan evaluasi (Ratnawulan \& Rahman, 2017). Evaluasi penting dalam melaksanakan suatu program. Evaluasi menyiratkan melihat ke belakang untuk lebih mengarahkan ke depan (Vedung, 2017). Perbaikan dan pengembangan program dilakukan bila ada laporan program yang telah berjalan. Pembuatan program tidak hanya didapat dari hasil need assesment. Pengembangan program yang baik diperoleh dari umpan balik pelaksanaan program sebelumnya. "... the purpose of the evaluation is to provide both decision making and program improvement" (Fitzpatrick, Christie, \& Mark, 2009). Tujuan utama evaluasi adalah membuat keputusan dalam peningkatan program.

Evaluasi dimulai untuk banyak tujuan, terkadang bertentangan: memilih prospek terbaik di antara beberapa jalur tindakan yang diusulkan, menyempurnakan program yang sudah beroperasi sedang dilaksanakan, mempertahankan kendali mutu, membuat pelaksana untuk mematuhi instruksi, mendokumentasikan bahwa agensi seseorang layak mendapatkan anggarannya, menciptakan dukungan untuk proyek hewan peliharaan, menimbulkan kecurigaan pada kebijakan yang disukai oleh lawan politik.... (Cronbach et al., 1980; Phillips, 2018). Evaluasi hasil belajar dapat disepakati untuk dilaksanakan dengan baik dalam pelaksanaannya selalu berpegang pada tiga prinsip utama, yaitu: (1) Prinsip Keseluruhan, (2) Prinsip Keberlanjutan, 3 Prinsip Objektivitas (Sudijono, 2008). Evaluasi menjadi hal yang penting dalam pelaksanaan sebuah program. Perbaikan dan pengembangan program dilaksanakan ketika ada pelaporan dari program yang telah berjalan. Pembuatan program tidak hanya didapatkan dari hasil need assessment. Pengembangan program yang baik justru didapatkan dari feedback pelaksanaan program sebelumnya. Evaluasi merupakan kegiatan yang bertujuan bukan hanya menggambarkan bagaiamana pelakasaan sebuah program. Namun juga bertujuan untuk memberikan keputusan dan peningkatan sebuah program di masa yang akan datang. 
Penelitian yang dilakukan oleh Hapsyah et al., (2019) menunjukkan bahwa 50\% guru BK memiliki pengetahuan yang baik tentang evaluasi BK, sebanyak 63 guru BK memiliki pendapat yang baik tentang evaluasi bimbingan dan konseling. Hasil kajian pelaksanaan evaluasi program BK menunjukkan bahwa 47\% guru BK melaksanakan evaluasi terhadap perencanaan program BK, 53\% guru BK melaksanakan evaluasi proses, $59 \%$ guru bimbingan dan konseling melaksanakan evaluasi proses, 59\% guru BK melaksanakan evaluasi terhadap perencanaan program BK. Hasil evaluasi dilaksanakan oleh guru BK, sedangkan evaluasi program konseling sebesar 53\%. Penelitian ini menunjukkan bahwa pelaksanaan evaluasi BK dipengaruhi oleh persepsi guru BK tentang evaluasi itu sendiri.

Penelitian lain serupa menjelaskan bahwa sikap guru bimbingan dan konseling terhadap evaluasi program bimbingan dan konseling cenderung memiliki sikap mendukung dengan persentase sebesar $57 \%$, sedangkan sikap guru yang cenderung menolak dengan persentase sebesar sebesar $43 \%$. Kedua hasil ini dipengaruhi oleh pemahaman, opini, perasaan dan kecenderungan perilaku yang mereka miliki serta faktorfaktor yang mempengaruhi terbentuknya sikap (Khoirunnisa, Setiyowati, \& Tjalla, 2013).

Penguatan dua penelitian di atas dilakukan oleh Febriani \& Triyono (2018) dalam penelitiannya yang berjudul Faktor Penghambat Pelaksanaan Evaluasi Program Bimbingan dan Konseling oleh Guru Bimbingan dan Konseling. Hasil penelitian ini mengungkapkan bahwa: 1) Sebanyak 31,1\% guru bimbingan dan konseling mengalami hambatan faktor internal pelaksanaan evaluasi program bimbingan dan konseling. 2) Sebanyak 28,4\% guru bimbingan dan konseling mengalami hambatan faktor eksternal pelaksanaan evaluasi program bimbingan dan konseling.

Data hasil penelitian ini dapat dikategorikan proses evaluasi yang dilakukan di sekolah menegah atas yakni:

(1) proses evaluasi tidak pernah dilakukan karena tidak ada personel guru BK dari S1 $\mathrm{BK}$;

(2) evaluasi dilaksanakan dengan tidak terstruktur. Evaluasi ini dilakukan hanya ketika terjadi permasalahan siswa maupun pelayanan BK;

(3) evaluasi dilakukan tiap tahun. Dari data yang didapatkan evaluasi ini bertujuan untuk pembuatan laporan yang kemudian dideseminasikan dengan pihak sekolah. Hasil evaluasi ini akan di pakai untuk perbaikan program;

(4) ecaluasi yang dilakukan setiap semester. Tidak jauh beda dari evaluasi tahunan evaluasi ini juga memiliki tujuan untuk melaporkan kegiatan bimbingan dan konseling selama satu semester;

(5) evaluasi mingguan yang dilaksanakan dengan pihak sekolah. Pada evaluasi ini keterlibatan pihak sekolah seperti walikelas bertujuan untuk mengetahui perkembangan peserta didik;

(6) evaluasi yang dijalankan setiap kali program dijalankan. Berbeda dari beberapa evaluasi di atas, evaluasi ini bertujuan untuk mengetahui keterlaksanaan pelayana BK dan tindak lanjut apa yang dapat dilakukan dari ketercaiapan program.

Tujuan pelaksanaan evaluasi meliputi: 
(1) Untuk mengetahui tingkat keterlaksanaan kegiatan dan ketercapaian tujuan program yang telah ditetapkan;

(2) Menjadi dasar bagi guru bimbingan dan konseling/konselor untuk mengembangkan dan memperbaiki program selanjutnya;

(3) Umpan balik bagi pelaksana program bimbingan dan konseling dalam rangka perbaikan atau peningkatan implementasi program selanjutnya. Dari data yang diperoleh kebanyakna evaluasi yang dilakukan bertujuan untuk poin ke tiga yakni sebagai umpan balik.

Evaluasi merupakan proses penyelidikan untuk mengumpulkan dan mensintesis bukti yang berujung pada kesimpulan tentang keadaan ketidaksesuaian, nilai, prestasi, nilai, signifikansi kualitas dalam suatu program, orang, produk, kebijakan, proposal, atau rencana (Mertens \& Stewart, 2014). Ditambahkan oleh Mathison evaluasi akan menghasilkan dua aspek yakni; empiris dan normative (Mathison, 2004). Aspek empiris berbagai kasus atau permasalah yang terjadi dari pelaksanaan program. Aspek normative berisi tentang penilaian terhadap pelaksaan sebuah program.

Proses evaluasi yang dilakuakn dari beberapa sekolah menunjukkan bahwasanya belum adanya proses evaluasi terhapa program BK yang dilakukan secara komprehensif dengan meletakkan evaluasi sebagai bagian penting dalam pelayanan BK. Ada beberapa hal yang mendasari mengapa guru BK belum melaksanakan evaluasi dengan tepat yakni: keterbatasan waktu dan kurangnya pemahaman tentang evaluasi. Sejalan dengan hal tersebut Myrick menjelaskan alasan mengapa guru tidak melakukan evaluasi yakni; Tidak memiliki waktu, Tidak memiliki pengetahuan \& keterampilan, Ketakutan thd akuntabilitas, Perasaan nyaman, Persepsi bahwa hasil sulit diukur (Myrick, 2003). Di satu sisi evaluasi program bimbingan dan konseling bertujuan untuk meningkatkan praktik penyelenggaraan program bimbingan dan konseling itu sendiri, dan di sisi lain evaluasi merupakan alat untuk meningkatkan akuntabilitas program bimbingan dan konseling di mata pemangku kepentingan., seperti guru, kepala sekolah, orang tua, dan khususnya siswa (Khairunisa et al., 2019).

\section{SIMPULAN}

Gambaran pelaksaan evaluasi terhadap program pelayanan BK di sekolah menengah atas terbagi menjadi enam tipe. Dari keenam tipe tersebut masih banyak sekolah yang belum menerapkan proses evaluasi dengan tepat. Hal ini tentu membutuhkan peran guru dan pemangku kebijakan untuk membuat sebuah terobosan sehingga proses evaluasi berjalan dengan sistematis.

\section{UCAPAN TERIMAKASIH}

Ucapan terimakasih ditujukan kepada mahasiswa yang telah membantu keterlaksanaan penelitian ini.

\section{DAFTAR PUSTAKA}

Arikunto, S. (2019). Dasar-dasar Evaluasi Pendidikan (edisi revisi).

Cronbach, L. J., Ambron, S. R., Dornbusch, S. M., Hess, R. D., Hornik, R. C., Phillips, D. C., ... Weiner, S. S. (1980). Toward reform of program evaluation. Citeseer.

Febriani, R. D., \& Triyono, T. (2018). Faktor Penghambat Pelaksanaan Evaluasi Program 
Bimbingan dan Konseling oleh Guru Bimbingan dan Konseling. Jurnal Counseling Care, 2(1), 21-27.

Fitzpatrick, J., Christie, C., \& Mark, M. M. (2009). Evaluation in action: Interviews with expert evaluators. Sage.

Gysbers, N. C., \& Henderson, P. (2014). Developing and managing your school guidance and counseling program. John Wiley \& Sons.

Hapsyah, D. R., Fitriyani, N., Handayani, R., Nurmalia, T., Jabbar, A. A., Purwanto, D., $\&$ Badrujaman, A. (2019). Hubungan Antara Sikap Terhadap Evaluasi Guru BK dengan Keterlaksanaan Progam Bimbingan dan Konseling. Jurnal Renaissance, 4(02), 564-571.

Hennink, M., Hutter, I., \& Bailey, A. (2020). Qualitative research methods. SAGE Publications Limited.

Huberman, M., \& Miles, M. B. (2002). The qualitative researcher's companion. Sage.

Khairunisa, K., Rustam, A., Nurkholis, I., Mansyur, A. I., Maslikhah, M., \& Badrujaman, A. (2019). Hubungan antara Keterampilan Evaluasi dengan Keterlaksanaan Evaluasi Program BK di SMA Se-Kecamatan Cilinci Jakarta Utara. JKI (Jurnal Konseling Indonesia), 5(1), 21-27.

Khoirunnisa, R., Setiyowati, E., \& Tjalla, A. (2013). Sikap Guru Bimbingan dan Konseling terhadap Evaluasi Program Bimbingan Dan Konseling (Survey pada Guru Bimbingan dan Konseling SMP di Bekasi Timur). INSIGHT: Jurnal Bimbingan Konseling, 2(1), 87-93.

Lichtman, M. (2012). Qualitative research in education: A user's guide. Sage publications.

Lincoln, Y. S. (n.d.). dan Guba, EG (1985). Naturalistic Inquiry.

Mappiare, A. (2013). Tipe-tipe metode riset kualitatif untuk eksplanasi sosial budaya dan bimbingan konseling. Malang: Elang Mas Bersama Prodi Bimbingan Dan Konseling Fakultas Ilmu Pendidikan Universitas Negeri Malang.

Mathison, S. (2004). Encyclopedia of evaluation. Sage publications.

Mertens, D. M., \& Stewart, N. (2014). The feminist practice of program evaluation. Feminist Research Practice: A Primer, 330-362.

Myrick, R. D. (2003). Accountability: Counselors count. Professional School Counseling, 6(3), 174-179.

Phillips, D. C. (2018). The Many Functions of Evaluation in Education. Education Policy Analysis Archives, 26(46).

Ratnawulan, T., \& Rahman, S. A. (2017). MANAGEMENT PROFILE OF GUIDANCE AND COUNSELING IN JUNIOR HIGH SCHOOL. PEOPLE: International Journal of Social Sciences, 3(3).

Shertzer, B., \& Stone, S. (1966). Foundations of Guidance. New York: Houghton Mifflin Company.

Sink, C. A., Cooney, M., \& Adkins, C. (2017). Conducting Large-Scale Evaluation Studies to Identify. International Handbook for Policy Research on School-Based Counseling, 133.

Sink, C. A., \& Spencer, L. R. (2005). My Class Inventory-Short Form as an 
accountability tool for elementary school counselors to measure classroom climate. Professional School Counseling, 9(1), 2156759X0500900112.

Sudijono, A. (2008). No Pengantar Evaluai Pendidikan. Jakarta: PT. Raja Grafindo.

Sugiyo, S., \& Muslikah, M. (2018). Evaluation Models of Guidance and Counseling Service Based Cipp in Senior High School. In 4th International Conference on Early Childhood Education. Semarang Early Childhood Research and Education Talks (SECRET 2018). Atlantis Press.

Sukardi, D. K. (n.d.). Kusmawati.(2008). Proses Bimbingan Dan Konseling Di Sekolah. Jakarta: Rineka Cipta.

Sukardi, D. K., \& Kusmawati, D. P. E. N. (2008). Proses Bimbingan dan Konseling di Sekolah: untuk Memperoleh Angka Kredit. Jakarta: Rineka Cipta.

Tohirin, A., \& Pd, M. (2007). Bimbingan Dan Konseling Di Sekolah Dan Madrasah. Jakarta: Raja Grafindo Persada.

Vedung, E. (2017). Public policy and program evaluation. Routledge.

Whiston, S. C., Mitts, N. G., \& Li, Y. (2019). Evaluation of career guidance programs. In International handbook of career guidance (pp. 815-834). Springer. 